\title{
6: 116488614-116369687
}

National Cancer Institute

\section{Source}

National Cancer Institute. 6:116488614-116369687. NCI Thesaurus. Code C42338.

Physical location of FRK_Gene 